6

\title{
有機EL照明
}

\section{鈴木譲治 ${ }^{\dagger}$, 田中純一†, 森本満}

キーワード 照明, マルチフォトンエミッション, タンデム, リニア蒸発源, ゲル封止

\section{1 ま え がき}

有機 EL 照明は，従来の光源である電球や蛍光灯とは まったく異なり ${ }^{1)}$ ，陽極からホール，陰極から電子が注入 され，有機発光層中で再結合して失活する時に，そのエネ ルギーが光として放出されて発光する電界発光型の固体照 明デバイスである ${ }^{2)}$. 近年市場に浸透し始めたLED照明と は類似の発光原理を持つ. 特徵は, 薄型, 軽量, 面発光, 紫外線レスで目に優しい, 省電力で発熱が少ない, 高演色 で色再現性が良い，長寿命であるなどを併せ持っている. 素子に注入する電流值を変えればそれに応じた明るさ調節 ができることもあり，これらを活かした用途開発に注目が 集まっている.

2011年から本格的な市販が行われるようになり，近年の 性能改善は目覚しい. 現在では明るさ (全光束, $l \mathrm{~m}$ ) $50 \mathrm{~lm}$ $\sim 190 \mathrm{~lm}$, 色温度で, 電球色 $(2,800 \mathrm{~K}) \sim$ 昼白色 $(5,000 \mathrm{~K})$ まで，色再現性 (演色性, Ra) に打いても Ra90 以上の高演 色性が実現され，形状は $100 \mathrm{~mm} \square \sim 280 \mathrm{~mm} \times 100 \mathrm{~mm}$ 程 度までのパネルが発売されている3 ${ }^{4)}$. 発光効率について は40〜50 lm/W 程度まで製品として実現されており，白 熱電球を凌ぎ蛍光灯に近づきつつある. 発光寿命において も光束 $30 \%$ 減で 1 万時間以上を実現し, 蛍光灯と同等以上 になってきている. 発売されている有機 EL照明パネルの 例を図1に示す。

このように最近の性能向上は目覚しいが，本格的な普及 のためにはもう一段の性能向上とコスト低減が必須であ る. 本稿では, 最近の開発状況と課題や今後の開発の方向 性などについて当社の例を中心に述べる.

2 有機EL照明パネルの性能とマルチフォト

$$
\text { ンエミッション素子 }
$$

照明パネルでは輝度が数百 $\mathrm{cd} / \mathrm{m}^{2}$ のデイスプレイとは異 なり, 光量が必要なため数千 $\mathrm{cd} / \mathrm{m}^{2}$ の高い輝度と, 色温度 の異なる白色 ${ }^{5)}$ が要求される。これを满足させるためには

$\dagger$ Lumiotec 株式会社

"OLED Lighting Panel" by Joji Suzuki, Junichi Tanaka, Mitsuru Morimoto (Lumiotec Inc., Yamagata)

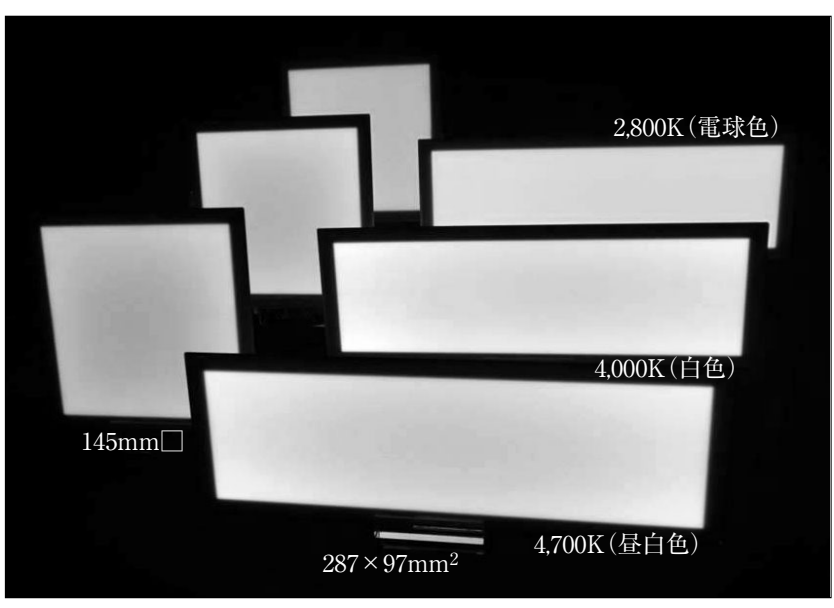

図 1 有機EL照明パネルのラインナップ例 (Lumiotec) （口絵カラ一参照）

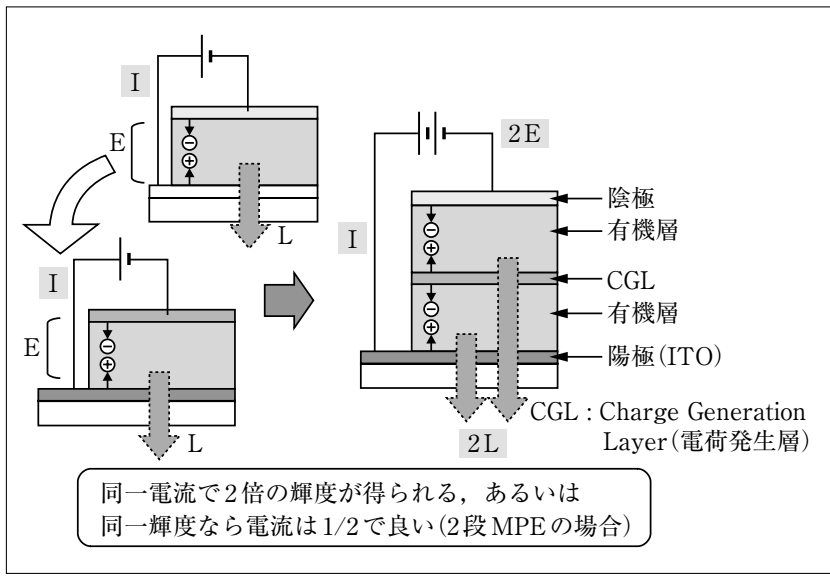

図2 マルチフォトン素子の原理

マルチフォトンエミッション素子 (MPE素子またはタンデ 么構造素子) 構造 ${ }^{6)}$ が最適である. 本素子は有機 $\mathrm{EL}$ 素子の ユニットを，正負のキャリヤを発生させる電荷発生層 （CGL）を介して直列に積層した構造を持つ．2段のMPE素 子の例をとると，直列なので電流は 1 ユニット (段) 分と同 じでも輝度は 2 倍になる。このとき，電圧は 2 倍になるの で発光効率 $(l \mathrm{~m} / \mathrm{W})$ は1段素子と同じである (図2). 

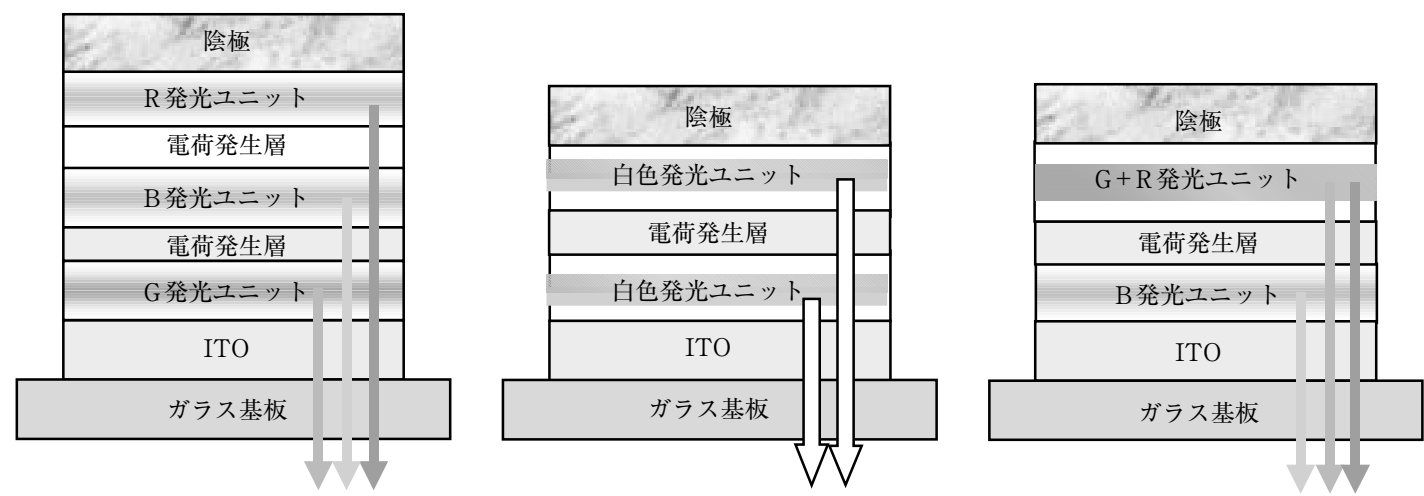

図3 白色MPE(Multi Photon Emission) 素子構造の例（ロ絵力ラ一参照）

白色を得る手法として青色 (B) と黄色 $(\mathrm{Y})$ の補色を使う 場合と青色 $(\mathrm{B})$, 緑色 $(\mathrm{G})$, 赤色 $(\mathrm{R})$ の 3 色を利用する手 法がある. 色温度と演色性の設計のし易さから後者の構造 をとるパネルが一般的となっている．この場合，1段素子 でBGR3色各々を実用的な最適強度と発光効率で発光させ ることは，各色のキャリヤバランスを取り難く困難である. MPE素子構造を用いれば1段目を $\mathrm{B} ， 2$ 段目を $\mathrm{G}+\mathrm{R}$ とする ことで比較的容易に色温度, 演色性, 発光効率の設計がで きる.また，後述するように1段目を蛍光発光のB素子, 2 段目を燐光発光の $\mathrm{G}+\mathrm{R}$ など異なる材料系の素子の積層も可 能であり ${ }^{7)}$ ，素子設計の自由度が高い(図3).

\section{3 輝度寿命の改善}

有機EL照明パネルの実用化にあたり輝度寿命の改善は 重要な課題の一つである. 有機 EL照明パネルの実用輝度 域の寿命は駆動電流值の $1.5 \sim 2$ 乗に反比例して短くなる ${ }^{8)}$ という性質があり, 光量を得るために輝度を上げようとす ると, 駆動電流值の増大を伴うため輝度寿命が大幅に短く なるという問題があった.これについても, 前述の MPE 素子構造をとることにより解消できる. 例えば， 2 段 MPE 素子であれば 1 ユニット素子と同じ電流值で 2 倍明るくで き, 駆動電流值の増大を伴っていないため, 寿命は短くな らずに高輝度が維持できるということになる. 多段化によ り陽極・陰極間の抵抗值は増加するが, 素子の電極間抵抗 に比して陽極ITOの抵抗が相対的に低下するため, 輝度の 面内バラツキが低下するので, 高輝度と長寿命が両立でき ることも合わせ, 大面積な照明パネルにおいては必須の技 術といえる.

また素子構造だけでなく, 材料メーカを中心に有機材料 自体の性能向上にも取組まれており, 高性能な材料の探索 が続けられている. 発光層材料はもちろんのこと, 輸送層 材料など周辺材料も含め, 総合的なアプローチがなされて いる. その結果, 特に赤色, 緑色領域では, 高効率かつ長 寿命な燐光材料が開発されてきている. しかし, 波長の短

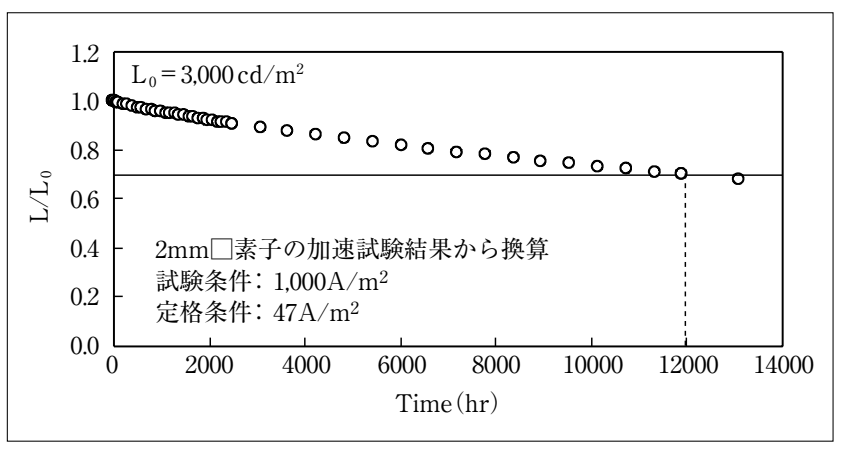

図4白色パネル (4,000K) の輝度寿命 $(\mathrm{L}$ 社)

い青色領域では，まだ実用的な燐光材料は実現できておら ず今後の開発が期待される.

現状では, 青色に蛍光材料, 緑色, 赤色に燐光材料を使 用し， MPE構造を適用することで，4,000K の白色で初期 輝度 $3,000 \mathrm{~cd} / \mathrm{m}^{2}$, 光束 $30 \%$ 減寿命が 12,000 時間の照明パネ ルが実現できている(図4).

\section{4 発光効率の改善}

発光効率 $(l \mathrm{~m} / \mathrm{W})$ の改善は省エネ化の観点から重要な課 題である。このためには駆動電圧の低減を図るとともに, 単位電流あたりの光束 $(\mathrm{lm} / \mathrm{A})$ を増加させる必要がある.

素子の低電圧化を実現するためには, 電子およびホール といったキャリヤの移動度が高い電荷輸送材料を適用する ことが効果的である。また電極ならびに隣接する有機層か らのキャリヤ注入障壁を低減するために, イオン化ポテン シャル $(\mathrm{Ip})$ や電子親和力 (Ea) といったエネルギーレベル について，各材料間にて整合を図る必要がある．当社の製 品パネルについては，これらを考慮したデバイス設計を実 施している.

一般的に駆動電圧の理論下限值は, 発光材料のバンド ギャップによっておよそ決まるが，有機材料自体のキャリ ヤ移動度はシリコンなどの無機半導体材料に比べ数桁低い 


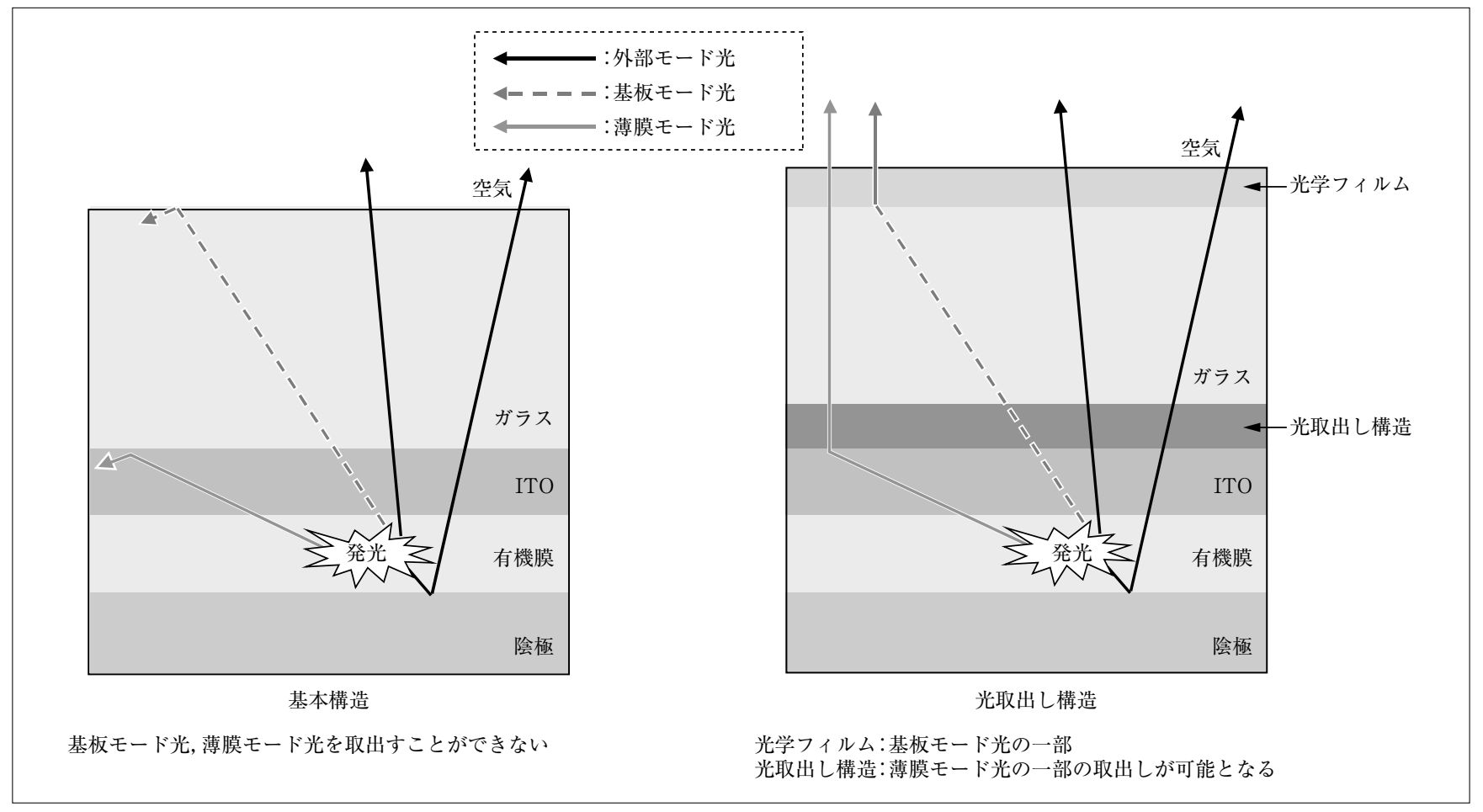

図5 光取出し構造

ことから, 有機層の膜厚を薄膜化することによっても，あ る程度の低電圧化は可能である. しかしこの場合はパネル のショート確率が高くなり, 結果として製品歩留まりの低 下に繋がることもある。この事象に対する解決策として, 前述したMPE構造が挙げられる。

具体的には, 低電圧化のために各ユニットの膜厚を発光 効率や寿命に影響を及ぼさない程度にまで極力薄くし，そ れらのユニットを複数段積層してMPE化を行う手法であ る.これにより, 各ユニットの駆動電圧を低下させつつ, 有機層全体を厚膜化させることが可能となる. 結果, MPE 化しても比較的低電圧な素子と高歩留まりの両立が実現可 能となり, 有機EL照明パネルの量産においてその恩恵は 大きい.

一方で, 単位電流あたりの光束を増加させる方法として は, 光取出し効率の改善が重要な技術となる. 有機膜内に て発生した光は，以下のモードに大別できる ${ }^{9)}$.

(1) 外部モード : 外部に光 (光束) として取出せる放射成分

（2）基板モード：ガラス基板内に留まる非放射成分

(3) 薄膜モード : 有機膜内にて損失する非放射成分

(2) は, ガラス内に入射した一部の光が, 大気との屈折 率差による臨界角の影響により, 外部へ放射されない現象 である．対策として基板表面へピラミッドやマイクロレン ズ形状を付与した光学フィルムを導入することが有効であ る. 当社の製品パネルにはフィルムメーカと共同開発した 光学フィルムを採用しており, 光学フィルムおよびデバイ ス構造の双方から構造最適化を行うことで, パネル特性の
改善を図っている.

（3）については，素子内部にての干渉の影響や素子とガ ラス基板との屈折率差による臨界角の影響によりガラス基 板中へ放射されない成分や，陰極表面におけるプラズモン 損失などによるロス分であり，その割合は全体の $50 \%$ 程度 と非常に大きい10)11). 改善策として, パネル構造に散乱性 を有する光取出し構造を付与することで, これらの成分を 外部へ取出す方式について検討が進められ，一部実用化さ れている (図5). 当社においても次期製品パネルでの適用 に向けた開発を進めている。

\section{5 白色の設計}

有機 $\mathrm{EL}$ 素子の構造設計を行う場合, 発光部から反射電 極 (㓌極) 界面までの距離が波長以下と短いことから, 干渉 効果についての考慮が必要となる. 正面方向への発光を強 調する場合には, 発光点から反射電極までの光学距離 $d$ を $\lambda / 4$ とすると良い. しかし, 全光束 $(\mathrm{lm})$ を重視する照明 用途に対してこの干渉条件は必ずしも最適ではなく12)，ま た前述した光学フィルムの併用を前提とした場合, フィル 厶の効果を極大化させるために広角成分を増大させる配光 設計を取る必要がある。これらの効果を検証するために, 緑色蛍光素子において干渉条件を変えたデバイスの作製を 行い，特性を評価した結果を図6に示す。

正面設計は $d=\lambda / 4$ に設定し, 設計 $\mathrm{A}$ は全光束值が最大 となる距離を, 設計 $\mathrm{B}$ はフィルムによる光取出し効率が最 大となる距離をそれぞれ光学シミュレーションにより算出 


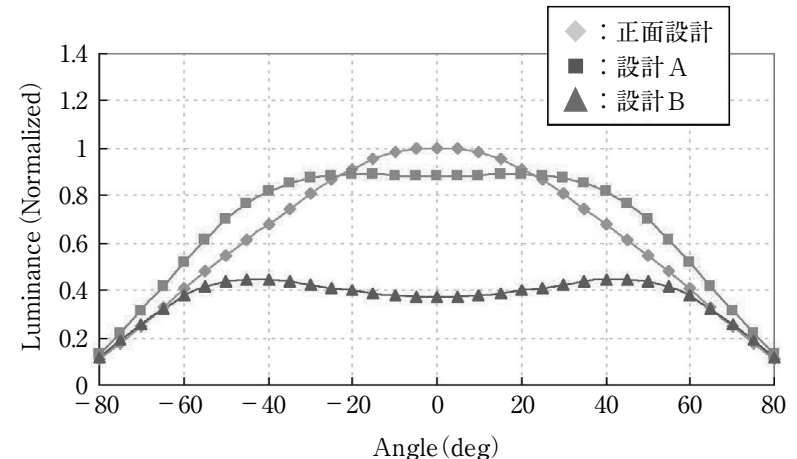

(a) 素子単体の配光特性

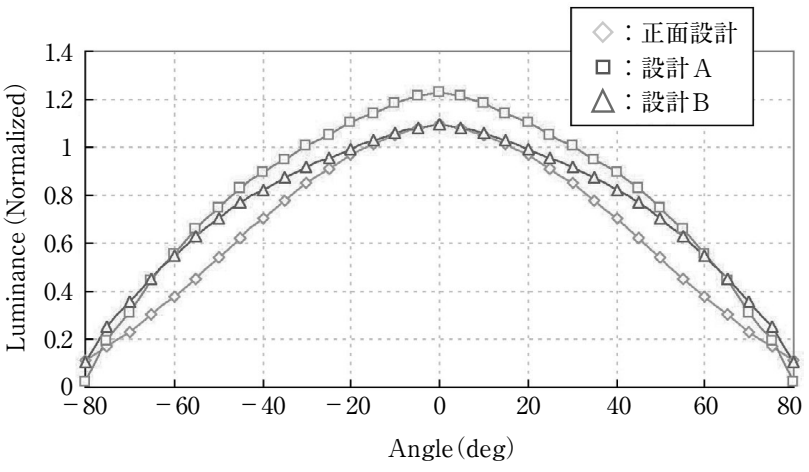

(b) 光学フィルム併用時の配光特性

図6 素子の配光特性と干渉設計（口絵力ラ一参照）

表 1 干渉設計の相違による発光効率の特性差

\begin{tabular}{|c|c|c|c|c|c|c|}
\hline \multirow{2}{*}{$\begin{array}{l}\text { 全光束測定値 } \\
\text { (緑色単色素子) }\end{array}$} & \multicolumn{2}{|c|}{ 光学フィルムなし } & \multicolumn{2}{|c|}{ 光学フィルムあり } & \multicolumn{2}{|c|}{$\begin{array}{c}\text { 光学フィルムによる } \\
\text { アップ率 }\end{array}$} \\
\hline & $\begin{array}{c}\mathrm{EQE} \\
(\%)\end{array}$ & $\begin{array}{c}\text { 光源の光束 } \\
\left(\mathrm{lm} / \mathrm{m}^{2}\right)\end{array}$ & $\begin{array}{l}\text { EQE } \\
(\%)\end{array}$ & $\begin{array}{c}\text { 光源の光束 } \\
\left(\mathrm{lm} / \mathrm{m}^{2}\right)\end{array}$ & $\mathrm{EQE}$ & 光源の光束 \\
\hline 正面設計 & 6.2 & 7,001 & 8.1 & 9,182 & 1.31倍 & 1.31倍 \\
\hline 設計A & 7.1 & 8,238 & 9.5 & 10,921 & 1.34倍 & 1.33倍 \\
\hline 設計B & 4.5 & 5,695 & 8.4 & 9,742 & 1.87倍 & 1.71倍 \\
\hline
\end{tabular}

し，デバイス化を行った.

図 6 (a)に素子単体の配光特性を示す. 正面設計は $0^{\circ}$ $20^{\circ}$ の範囲にて最も輝度が高く, 一方で設計 $\mathrm{A}$ は $30^{\circ}$ 以降 の角度にてやや発光成分が増えていることが読取れる。 そ れに対し設計 $\mathrm{B}$ は輝度の絶対値こそ低いものの, $45^{\circ} \sim 60^{\circ}$ 付近にピークを有しており，広角成分が多く含まれている ことが確認された。

これらに光学フィルムを適用した際の配光特性を図6(b) に示す．設計 A では全角度において正面設計を上回る特性 が得られ, 設計 $\mathrm{B} て ゙ は$ 光取出し効率が大幅にアップするこ とを確認した. 表1に特性一覧を示すが, 光学フィルム使用 時には, 正面設計に対し設計 $\mathrm{A}, \mathrm{B}$ 共に外部量子効率 (EQE), および光束 $\left(\mathrm{lm} / \mathrm{m}^{2}\right)$ において良好な特性が得られた。

一方で白色発光素子の光学設計を考えた場合, 白色光は 単色光に比ベスペクトルのバンド幅が広いことからコヒー レンス長は短くなるものの, 干渉の影響を受けることから 上記と同様の設計思想を踏襲できる. しかし, 層を構成す る各材料の屈折率は波長分散を有するので, 複数の波長成 分が混在している白色光では, すべての波長に対して一元 的に最適な光学距離を決定することは困難であることに注 意を要する.

当社では, 素子の設計自由度が高い MPE 構造をべース にした光学膜厚の計算を行い, 白色の各構成波長に対して 整合性を有する膜厚の設計を行っている．その際にパネル の演色性や視野角依存性 (パネルを見る方向によって色調
が変化する現象）といった照明光源に必要な特性について も考虑することで，実用的な性能を確保している13).

\section{6 製造プロセス}

有機 $\mathrm{EL}$ 照明パネルの構造，製造プロセスとも近年ス マートフォンなどで広く使用されている有機ELディスプ レイと類似のものである．最も大きな違いは，パネル全体 を1画素で構成する場合が多く，ディスプレイのように多 数の微細な画素を形成しなくて良いことと，その個々の画 素を独立に駆動するための複雑な回路（TFT 基板やドライ バIC) が不要であることである．ただし，MPE構造をとり 多数の有機層やCGL層が必要であるので，膜厚の制御や光 干渉の制御を精密に行う必要がある.

当社の例では, 素子形成において, 量産に適した「リニア 蒸発源搭載インライン成膜装置」を用いて，2009年8月から 現在まで開発試作や生産にフル稼働してきた. 有機発光層 の成膜においては，3種類の材料を共蒸着ができるような蒸 発源配置となっている ${ }^{14)}$. MPE構造の素子を効率良く製造 するために，リニア蒸発源を有機層の層数分数十個並べた 装置である.インライン装置として，世界でも初めてのシ ステムであるが，安定した稼動に成功している(図7).

一方，有機EL素子は水分や酸素に弱いので，素子を外 気とは隔離する必要がある。通常2枚のガラス板で素子を 挟み込む構造をとり，有機 $\mathrm{EL}$ 素子を形成した基板ガラス の上に封止ガラスを低露点の窒素中で貼り合せる必要があ る.一般的には高価な掘込みガラスにシール状の吸湿剂を 貼り付けたキャップ内部を窒素で充填する方法で封止が行 われる。

当社の封止に拉いては，高価なキャップガラスを用いず 平板ガラスを使用し，伝熱性が良いゲル材料に吸湿性を持 たせこれをサンドイッチした，ゲル充填封止を採用してい る。本工法はLCDに扔ける ODF (One Drop Fill：液晶滴 下注入) プロセスが応用できるなど量産性も良い(図8). 


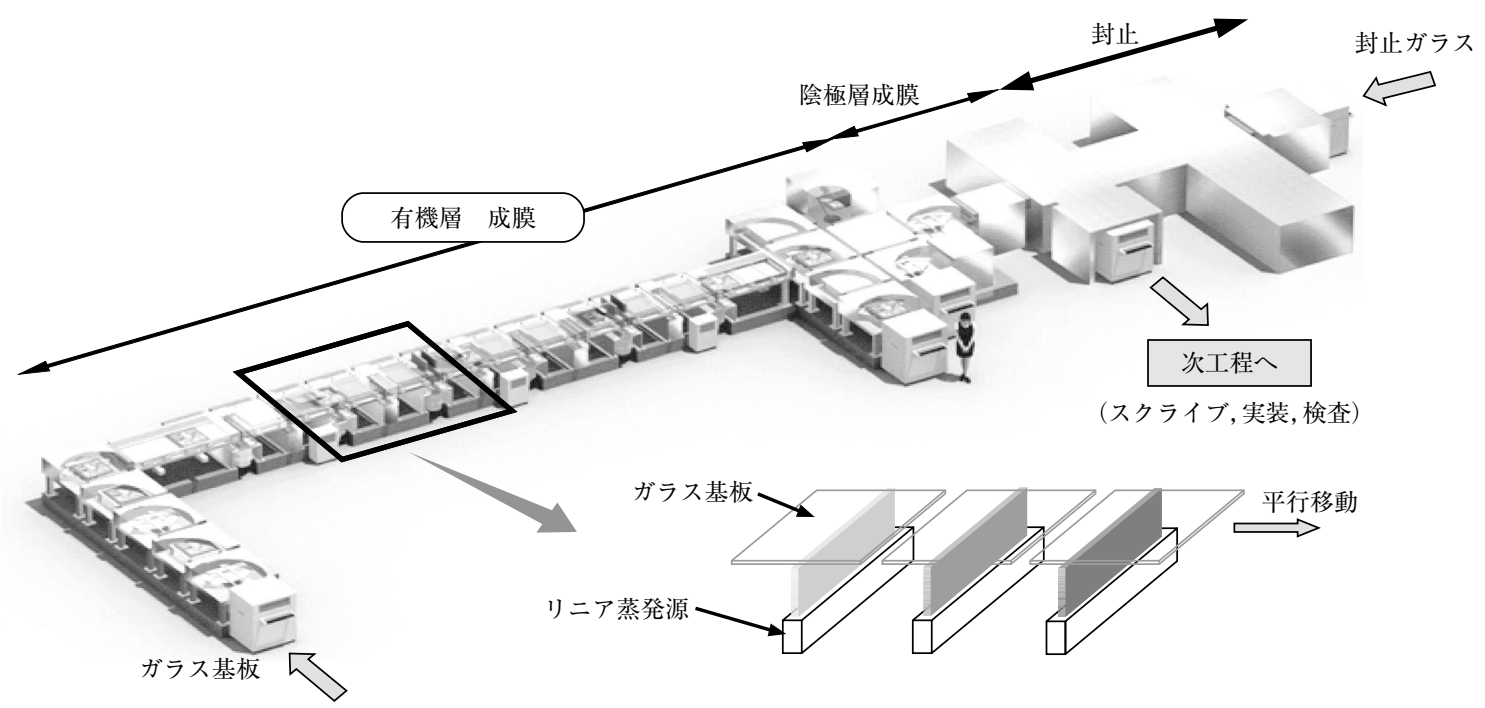

図7量産ライン概念図 (リニア蒸着源インライン装置)（ロ絵カラ一参照）
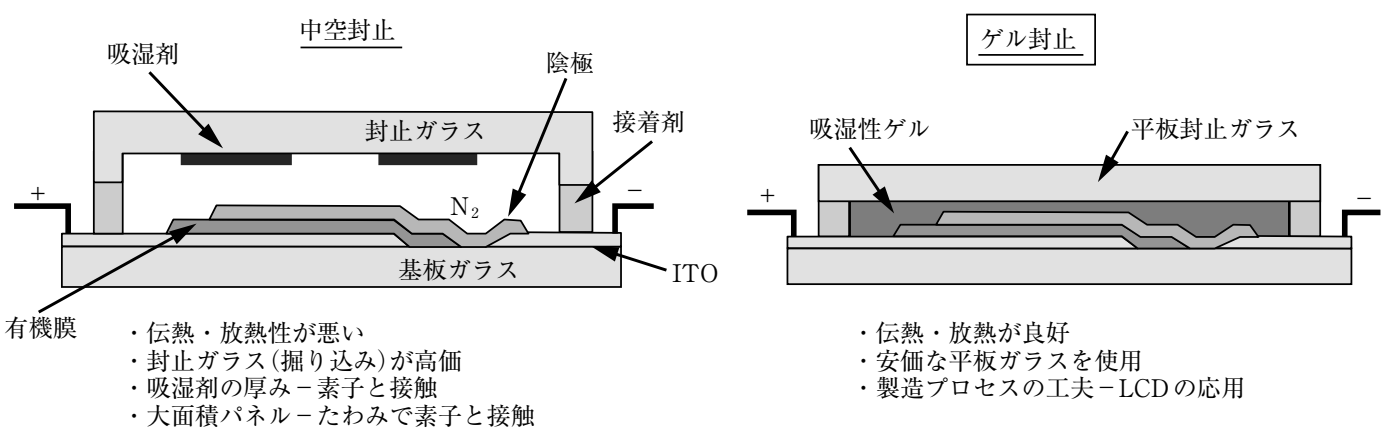

図8 ゲル封止構造

\section{7 最近の製品化の状況}

有機 EL照明パネルの性能が着実に向上してきている中, 演色性など照明光源としての特性にも着目したパネル開発 がなされ, 薄型拡散面光源としての特徴を活かした適用事 例が増えてきている.

最近の国内の実使用例としては，高演色性，発熱が小さ い，紫外や赤外の有害光線を持たないといった特徴から， 美術館や博物館での使用例が出てきている. 図9に東京国 立博物館にて国宝の展示に使用された例を示す．従来とは 異なる照明としてデザイン領域でも注目されており，多く の照明器具が提案されているが，斬新なデスクライトとし て使用された例を図10に示す.

現状, 美術館や博物館, デザイン照明など比較的限られ た用途での製品化が主であるが，今後の性能向上，コスト 低減により，一般照明用途を含めた広範な平面照明への展 開が期待される。

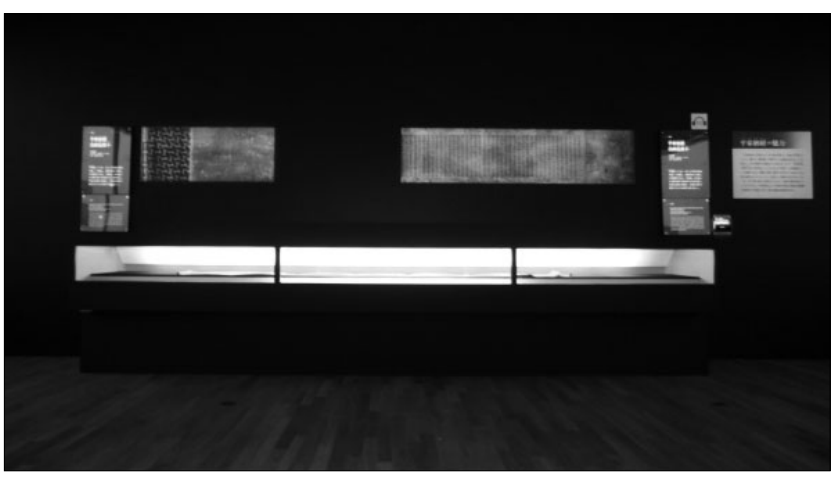

図9博物館の展示ケース照明(東京国立博物館, 2013年) (口絵カラ一参照)

また，有機ELならではの特徴を生かした試作品も多く 提案されてきている，通常，アルミ膜などを用いる金属電 極をITOなどで透明電極化して，非点灯時には透明な照明 や，樹脂基板や極薄のガラス上に有機EL素子を形成した 曲がる照明などである。まだ課題は多いが，既存の照明に 


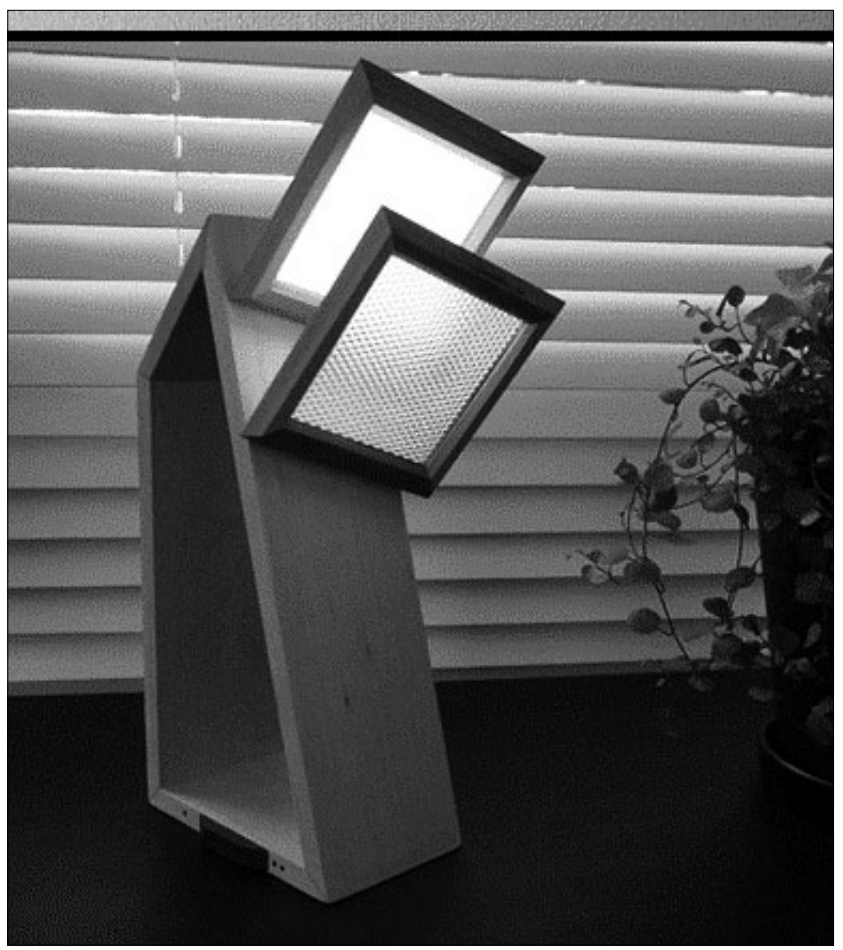

図 10 デスクライト(Feel Lab, 2013年) (口絵力ラ一参照)

は無かったあかりを提供できるという点で新しい価值を創 造する期待がある ${ }^{15)}$.

8 むす び

徐々にではあるが有機 EL照明の実用化が始まりつつあ る. 当社は, 小規模量産可能な生産工程と製造技術を確立 し, 更なる高歩留り化, 高信頼化に向けた活動を継続して いる。 また, 高効率化, 長寿命化など性能改善への取組み も継続的に行っている．数年後には，これら技術の集大成 となる本格量産ラインを構築し, 本格的な次世代照明の普 及期に対応する予定である.

今後は，当社独自のマルチフォトンエミッション（MPE) 素子技術を駆使し,「高輝度・高効率・長寿命・優しいあ
かり」をキーワードに，更なる改善に向けて努力していく． 有機 $\mathrm{EL}$ 照明を通して，より快適な人に優しい照明空間が 提供できると確信しており，加えて今後の省エネルギー社 会に貢献していきたい.

(2013年 9 月 5 日受付)

\section{〔文 献〕}

1）照明学会：“新・照明教室光源（改訂版）”（2005）

2）筒井哲夫監修：“有機ELハンドブック”, pp.349-361（2004）

3）堀 恵一ほか：“三菱重工技報”，49，1，pp.50-55（2012）

4）鈴木譲治：“有機EL 討論会第15回例会予稿集”, S2-2（2012）

5）JIS Z 9112 ：“蛍光ランプの光源色㧍よび演色性による区分”

6）城戸淳二ほか：“第49回応物秋季予稿集”，27p-YL-3（2002）

7) T. Komoda, et al.: "SID2011 Digest", 72, 1, pp.1056-1059 (2011)

8）古川慶一ほか：“Konica Minolta Technology Report”, 9, pp.58-63 (2012)

9）三上明義：“有機EL技術開発の最前線”，p.13（2009）

10)竹添秀男ほか：“省エネ型有機発光デバイスの開発”，月刊ディスブ レイ 16，7，pp.34-38（2010）

11) A. Mikami and T. Goto: "SID2012 Digest", 51, 1, pp.683-686 (2012)

12)筒井哲夫監修：“有機ELハンドブック”, pp.203-228（2004）

13)高村 誠ほか：“三菱重工技報”，49，4，pp.107-112（2012）

14）小笠原ほか：“三菱重工技報”，46，1，pp.33-35（2009）

15）日経エレクトロニクス，2013年6月 24 日号，pp.43-49（2013）

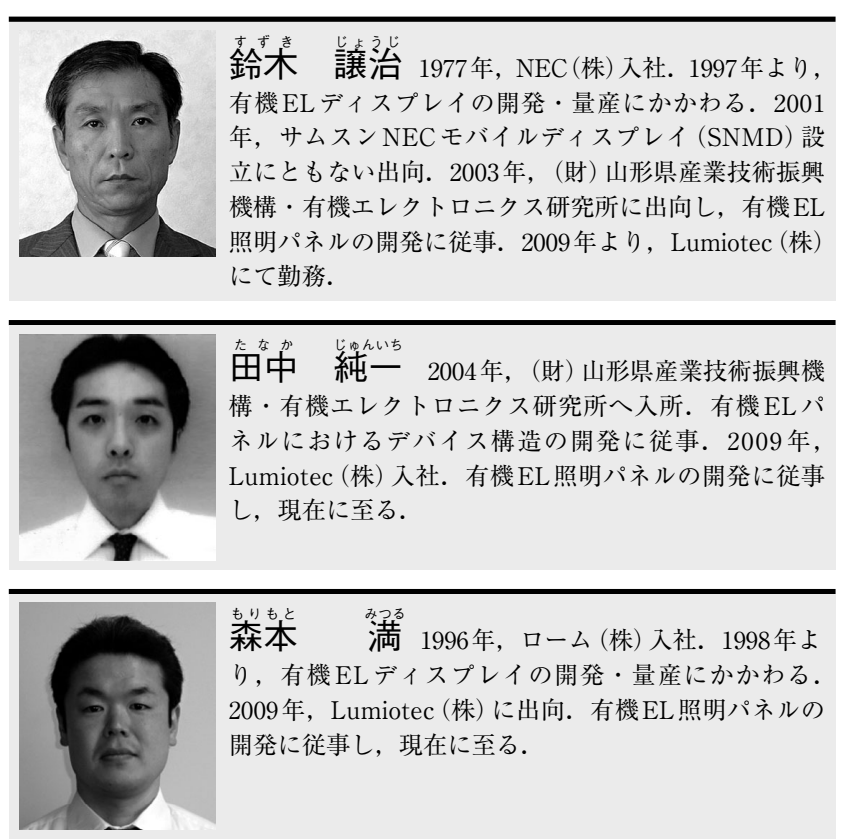

